University of Nebraska - Lincoln

DigitalCommons@University of Nebraska - Lincoln

Mammalogy Papers: University of Nebraska

State Museum

Museum, University of Nebraska State

$5-1-1967$

\title{
Notes on the Oaxacan Vole, Microtus oaxacensis Goodwin, 1966
}

J. Knox Jones Jr.

University of Kansas

Hugh H. Genoways

University of Nebraska - Lincoln, h.h.genoways@gmail.com

Follow this and additional works at: https://digitalcommons.unl.edu/museummammalogy

Part of the Zoology Commons

Jones, J. Knox Jr. and Genoways, Hugh H., "Notes on the Oaxacan Vole, Microtus oaxacensis Goodwin, 1966" (1967). Mammalogy Papers: University of Nebraska State Museum. 41.

https://digitalcommons.unl.edu/museummammalogy/41

This Article is brought to you for free and open access by the Museum, University of Nebraska State at DigitalCommons@University of Nebraska - Lincoln. It has been accepted for inclusion in Mammalogy Papers: University of Nebraska State Museum by an authorized administrator of DigitalCommons@University of Nebraska Lincoln. 


\section{NOTES ON THE OAXACAN VOLE, MICROTUS OAXACENSIS GOODWIN, 1966}

Goodwin (Amer. Mus. Novit., 2243: 1-4, 1966) named Microtus oaxacensis on the basis of a single male taken in "evergreen rain forest at Tarahundi, a ranch near the village of Vista Hermosa," at an altitude of "about 5000 feet" in the Mexican state of Oaxaca. On 25 June 1964, members of a field party from the Museum of Natural History, The University of Kansas, obtained two adult voles referable to oaxacensis in "dense cloud forest" southwest of Vista Hermosa (approximately 25 kilometers to the south of the type locality) as follows: male (KU 100046) from 61/2 mi. SSW Vista Hermosa, $7100 \mathrm{ft}$, trapped by Percy L. Clifton, and female (KU 100047) taken $10 \mathrm{mi}$. SSW Vista Hermosa, $8200 \mathrm{ft}$, by Arturo Jiménez G.

The skin of the holotype was prepared after initial preservation in formalin; even so, Goodwin's description of color is accurate as judged by our two specimens, both of which were in the process of molting. Molt on the male was nearly completed whereas that on the female still was in progress over a substantial part of the dorsum and, to a lesser extent, on the sides. The holotype lacked a tail, but the describer supposed the tail of oaxacensis "was relatively long" because the basal portion was thick. The tail appears to be relatively thick basally in our two museum skins, but it is not especially long. External and cranial measurements in millimeters of our two specimens (male and female, respectively, followed in parentheses by available published measurements of the holotype) are: total length, 163, 159; length of tail, 38, 31; length of hind foot, 22, 21 (22.5); length of ear, 14.5, 12; condylobasal length, 28.6, 28.2 (27.8); zygomatic breadth, 16.2, 15.8 (15.8); interorbital constriction, 4.0, 3.6 ("interorbital breadth," 4.4); lambdoidal breadth, 12.2, 12.0; length of nasals, 8.1, 7.9 (7.8); breadth of rostrum across nasolacrimal capsules, 6.1, 5.8; length of maxillary tooth-row, 7.8, 7.7 (7.5). The male and female (nonpregnant) weighed 43.2 and $37.6 \mathrm{~g}$, respectively.

Representatives of two other subgenera of Microtus occur in Oaxaca, Microtus (Orthriomys) umbrosus and Microtus (Pitymys) quasiater, from which $M$. oaxacensis can be distinguished by features characterizing the subgenus Microtus. Goodwin noted that oaxacensis superficially resembled quasiater in external features. Similarly, our specimens of oaxacensis resemble externally some individuals of Microtus guatemalensis (subgenus Herpetomys), which occurs as far west as central Chiapas.

The only other species of the subgenus Microtus known from Oaxaca is M. mexicanus. As Goodwin noted, oaxacensis can be distinguished from mexicanus by its decidedly smaller bullae, broader and flatter (not distinctly ridged) interorbital region, and generally flatter, longer, relatively narrower, and less angular skull. He also mentioned the short, narrow incisive foramina, and alluded to the prismatic pattern of the third upper molar of oaxacensis but did not specify how the molar pattern differed from that in mexicanus. In our material, the M3 of oaxacensis is composed of an anterior loop that is followed by a series of salient angles (five) and re-entrant angles (seven) and terminates in the heel typical of that tooth in Microtus. The salient and re-entrant angles form five triangles between the anterior loop and the heel, which are closed (anteriorly) or nearly so (posteriorly). In $M$. mexicanus, the M3 has but three salient angles and five re-entrant angles (thus only three triangles) between the anterior loop and the heel. Some other features, not mentioned in the original description, that serve to distinguish oaxacensis from mexicanus (subspecies fulviventer, fundatus, and mexicanus) are two pairs of pectoral mammae (rather than one), distinctly broader mesopterygoid fossa that is rounded (not V-shaped) anteriorly, and larger infraorbital foramina as viewed from the front and side (because the anterior border of the zygomatic plate is concave in oaxacensis and bows slightly outward).

Our specimens were captured in wet broadleaf evergreen forest admixed with a few 
pines and were taken in trap lines set under logs and stumps. The following small mammals were trapped in the same line $6 \frac{1}{2} \mathrm{mi}$. SSW Vista Hermosa: Sorex veraepacis mutabilis, Cryptotis magna, Cryptotis mexicana mexicana, Oryzomys alfaroi caudatus, Reithrodontomys microdon albilabris, Peromyscus melanocarpus, and Peromyscus thomasi cryophilus. Only $P$. melanocarpus was taken along with the vole from the other locality. -J. Knox Jones, Jr., and Hugh H. Genoways, Museum of Natural History, The University of Kansas, Lawrence, 66044. Accepted 23 December 1966. 